\title{
STRATEGI PEMASARAN JASA PENDIDIKAN DALAM MENINGKATKAN KUANTITAS SISWA
}

\section{MARKETING STRATEGY OF EDUCATION SERVICES IN INCREASING THE QUANTITY OF STUDENTS}

\author{
E Kustian'1a, 0 Abdurakhman', dan W Firmansyah' ${ }^{2}$ \\ ${ }^{1}$ Program Studi Manajemen Pendidikan Islam, Fakultas Keguruan dan Ilmu Pendidikan, \\ Universitas Djuanda Bogor, Jl. Tol Ciawi No. 1 Kotak Pos 35 Ciawi Bogor 16720 \\ 2 Program Studi Pendidikan Guru Sekolah Dasar, Fakultas Keguruan dan Ilmu Pendidikan, \\ Universitas Djuanda Bogor, Jl. Tol Ciawi No. 1 Kotak Pos 35 Ciawi Bogor 16720 \\ a Korespondensi: Eldi Kustian, Email: eldieldikustian@gmail.com \\ (Diterima: 09-07-2018; Ditelaah: 10-07-2018; Disetujui: 27-07-2018)
}

\begin{abstract}
This research aims to describe and to know the application of marketing strategy of educational services through the management functions and trought the theory og marketing mix in MA Daarul Uluum Bantar Kemang and find the factor endowments and a barrier that exists in MA Daarul Uluum in the marketing of educational services. The methods used in this research in descriptive qulitative approch, data collection techques, namely as for observation, interview, and documentation study. For observations done with the related observations of the activities of the marketing strategy of of educational services in increasing the number of new students. Parties in the interview is the principal, vice principal, administrative head, chairman of PAPENSIBA, theachers, students, and the student trustee. The study documentation is carried out by shooting directly and ask for documents or files which related to the marketing of educational service to the staff of TU. The result of this research show that: first, the marketing strategy of educational services to increase the quantity of students in the MA Daarul Uluum Bantar Kemang using management function that there are four stages. (1) the palnning stages namely; do segmentasi the market, and determining the target market, and determine the target market. (2) organizing stages namely; forming new student admission committee ( PAPENSIBA). (3) the stages of implementation, namely; marketing directly and indirectly. (4) the evaluation, namely; the time of implementation of the evaluation every year. Second, the implementation of the marketing strategy of educational services in MA Daarul Uluum Bantar Kemang to increase the quantity of students trough marketing mix namely; product, place, price, promotion, people, pysical evidence and processowned by MA Daarul Uluum quite management to increase the number of animo registrant learners every year. Third, the supporting factors in the marketing starategy of educational services in MA Daarul Uluum Bantar Kemang namely, the qualified educators, the geographical location of the school, are home to many activities of ektrakulikuler, directly under the auspices of the Foundation Daarul Uluum, and budgeting affordable school bugget by any other circles. Fourt, an inhibitor of factor in the marketing strategy of educational services in MA Daarul Uluum Bantar Kemang namely; the rivalry between instutions that increasingly tight, yet there are experts in the field of marketing, a very limited vehicle parking, lack of land owned by the school, and the students in out MA Daarul Uluum Bantar kemang.
\end{abstract}

Keywords: education services, marketing, strategy. 


\section{ABSTRAK}

Penelitian ini bertujuan untuk menggambarkan dan mengetahui penerapan strategi pemasaran jasa pendidikan melalui fungsi manajemen dan teori bauran pemasaran di MA Daarul Uluum Bantar Kemang dan menemukan Faktor pendukung dan penghambat yang ada di MA Daarul Uluum dalam pemasaran jasa pendidikan. Metode yang digunakan dalam penelitian ini adalah metode studi kasus dengan pendekatan kualitatif, adapun teknik pengumpulan data yaitu dengan observasi., wawancara, dan studi dokumentasi. Untuk observasi dilakukan dengan pengamatan terkait kegiatan strategi pemasaran jasa pendidikan dalam meningkatkan jumlah siswa baru. Pihak yang di wawancarai adalah kepala sekolah, wakil kepala sekolah bidang kemahasiswaan, kepala tata usaha, ketua PAPENSIBA, guru, siswa, dan wali siswa. Studi dokumentasi dilakukan dengan pengambilan gambar secara langsung dan meminta dokumen-dokumen atau berkas-berkas yang terkait dengan pemasaran jasa pendidikan kepada staf tata usaha. Hasil penelitian ini menunjukan bahwa: Pertama, strategi pemasaran jasa pendidikan untuk meningkatkan kuantitas siswa di MA Daarul Uluum Bantar Kemang dengan menggunakan fungsi manajemen itu ada empat tahapan. (1) tahap perencanaan yaitu; melakukan segmentasi pasar, penentuan target pasar, dan menentukan target pasar. (2) tahapan pengorganisasian yaitu; membentuk panitia penerimaan siswa baru (PAPENSIBA). (3) tahapan pelaksanaan yaitu; pemasaran secara langsung dan pemasaran secara tidak langsung. (4) evaluasi yaitu; waktu pelaksanaan evaluasi yaitu setiap tahun sekali. Kedua, implementasi strategi pemasaran jasa pendidikan di MA Daarul Uluum Bantar Kemang untuk meningkatkan kuantitas siswa melalui bauran pemasaran yaitu; produk, tempat, harga, promosi, people, pysical evidence, dan prosesyang dimiliki oleh MA Daarul Uluum cukup berhasil untuk meningkatkan jumlah animo pendaftar peserta didik di setiap tahunnya. Ketiga,Faktor pendukung dalam strategi pemasaran jasa pendidikan di MA Daarul Uluum yaitu, tenaga yang berkualitas, letak sekolah yang geografis, memiliki banyak kegiatan ektrakulikuler, langsung berada dibawah naungan Yayasan Daarul Uluum, dan anggaran pembiyaiaan sekolah yang terjangkau oleh kalangan manapun. Keempat, Faktor penghambat dalam strategi pemasaran jasa pendidikan di MA Daarul Uluum bantar Kemang yaitu; persaingan antar lembaga yang semakin ketat, belum adanya tenaga ahli dibidang pemasaran, parkiran kendaraan yang terbatas, kurangnya lahan untuk olahraga, kurang luasnya tanah yang dimiliki oleh sekolah, dan sering terjadi keluar masuknya siswa-siswi MA Daaarul Uluum Bantar Kemang.

Kata kunci: jasa pendidikan, pemasaran, strategi.

Kustian, E., Abdurakhman, O., \& Firmansyah, W. (2018). Strategi Pemasaran Jasa Pendidikan dalam Meningkatkan Kuantitas Siswa. Tadbir Muwahhid, 2(2), 87-97.

\section{PENDAHULUAN}

Laju perkembangan ilmu pengetahuan dan teknologi menuntut masyarakat untuk melakukan perubahan sehingga mampu mengikuti perkembangan zaman, zaman dimana iklim kompetitif sudah masuk di semua lini kehidupan. Dampaknya turut menciptakan persaingan yang semakin tinggi pada semua aspek kehidupan masyarakat. Di zaman modern ini sangat penting bagi masyarakat yang mau meningkatkan kemampuan mengikuti persaingan yang kompetitif dalam krisis multidemensi. Pendidikan dipercaya sebagai salah satu alat strategi dalam meningkatkan taraf hidup manusia melalui pendidikan, manusia menjadi cerdas, mempunyai kemampuan atau skill, sikap hidup yang baik, sehingga dapat bergaul dengan baik di masyarakat. 
Sekolah merupakan lembaga pendidikan yang bergerak dalam bidang jasa pendidikan. Selain itu kompetisi antar sekolah semakin ketat. Maka dalam ini penyelenggara pendidikan dituntut untuk kreatif dalam menggali keunikan dan keunggulan sekolahnya agar dibutuhkan dan diminati oleh pelanggan jasa pendidikan. Munculnya sekolah berwawasan internasional serta lahirnya sekolah negeri dan swasta yang menawarkan keunggulan fasilitas, program pembelajaran yang menarik, bahkan dengan biaya yang terjangkau, dapat menambah maraknya kompetisi pendidikan.

Tidak bias dipungkiri bahwa persaingan antar sekolah semakin ketat. Hal ini tentunya menjadi sinyal positif bagi sekolah dalam meningkatkan mutu pendidikan. Tentunya ini bias dibuktikan dengan adanya upaya-upaya yang sangat kreatif yang dilakukan oleh penyelenggara pendidikan untuk menggali keunikan dan keunggulan sekolah agar dibutuhkan dan diminati oleh masyarakat. Lahirnya sekolah-sekolah negeri dan swasta yang menawarkan berbagai keunggulan fasilitas, program pembelajaran yang menarik, bahkan dengan biaya yang sangat terjangkau, sangatlah berpengaruh terhadap maraknya kompetisi pendidikan.

Aktivitas pemasaran jasa pendidikan yang terdahulu dianggap tabu karena berbau bisnis dan cenderung berorientasi pada laba (profit oriented), sekarang ini sudah dilakukan secara terbuka dan terang terangan (Wijaya, 2012). Konsep input, proses dan output menjadi kajian yang telah dimantapkan dan inovasi-inovasi tersebut akan menjadi sebuah kajian pemasaran yang menarik. Upaya untuk mendapatkan calon siswa sebagai input yang cakap dan matang, telah menjadi tuntunan yang wajib dipenuhi dalam rangka mendukung proses pembelajaran dan kompetisi antar sekolah.

Pemasaran menjadi sesuatu yang mutlak harus dilakukan oleh setiap sekolah, karena untuk memperkenalkan dan mempromosikan dalam menarik sejumlah calon siswa baru. Maka dari itu sekolah dituntut untuk melakukan strategi pemasaran yang sangat baik guna mempertahankan dan menambah kuantitas siswa.

Saat ini, dunia pendidikan harus diperlakukan dan dikelola secara profesional, karena semakin ketatnya persaingan, lembaga pendidikan akan ditinggalkan oleh pelanggan pendidikan atau masyarakat jika dikelola seadanya. Setiap lembaga pendidikan mengetahui bahwa proses pembelajaran di sekolah tidak akan pernah statis, akan tetapi senantiasa dinamis mengikuti kemajuan ilmu dan teknologi yang semakin hari semakin berkembang pesat. Oleh karena itu sekolah sangat dituntut untuk lebih meningkatkan mutu dari semua sektor.

Lembaga pendidikan adalah sebuah kegiatan yang melayani konsumen berupa siswa dan masyarakat umum yang dikenal sebagai stakeholder. Lembaga pendidikan pada hakikatnya bertujuan untuk memberikan layanan dan pihak yang dilayani ingin memperoleh kepuasan dari layanan tersebut, karena mereka sudah membayar cukup mahal kepada lembaga pendidikan (Alma, 2005). Pemasaran jasa pendidikan disini tergolong dalam marketing jasa. Dimana lembaga pendidikan tidak mencari keuntungan semata, demi kemakmuran para pengurus atau pemilik lembaga.

Sebuah lembaga yang ingin sukses untuk masa depan dalam menghadapi persaingan diera melenial ini harus mempraktikan pemasaran secara terus menerus agar 
mendapatkan jumlah siswa yang dikehendaki, karena semakin meningkatkan atau calon siswa yang masuk dapat mengangkat citra positif pada sebuah lembaga di masyarakat.

Sekolah-sekolah yang memposisikan dirinya sebgai sekolah unggulan, andalan, ataupun pavorit yang diregulasi pemerintah kota bukan menjadi pilihan utama bagi masyarakat saat ini, karena tren siswa dewasa ini ternyata tidak hanya melihat keadaan sekolah unggulan, andalan dan favorit sebagai salah satunya pertimbangan untuk memutuskan bersekolah di lembaga tersebut, akan tetapi pertimbangan keadaan sekolah gaul dan dapat dipercaya ternyata menjadi fenomena baru dalam pemasaran lembaga pendidikan, hal ini sangat penting mendapatkan respon dari manajemen sekolah. Berkualitas, disiplin namun tetap gaul cenderung pula menjadi idealisme remaja serta sekolah dapat dipercaya dengan infrastruktur yang lebih mendukung, dan fasilitas teknologi yang memadai.

Hal ini ternyata merupakan prilaku konsumen pendidikan, siswa relatif ingin suasana dinamis dalam lingkungan sekolahnya, para wali siswa pun ingin anaknya tahu banyak tentang teknologi pendidikan mutakhir, sehingga sekolah lagilagi dituntut menawarkan inovasi dalam program-program sekolah apa saja yang akan ditawarkan.

Namun tidak hanya itu, yang lebih penting sebagai sikap yang harus dikembangkan yaitu membangun persepsi dan citra yang positif terlebih dahulu, mempunyai tujuan yang baik, saling mempercayai satu sama lain, saling menghargai, saling pengertian antar kedua belah pihak dan memiliki rasa toleransi. Untuk membangun citra positif dari masyarakat luas.
MA Daarul Uluum adalah lembaga pendidikan islam berbasis asrama dengan sistem yang moderen dan merupakan lembaga pendidikan menengah atas yang berada di bawah naungan Yayasan Daarul Uluum Uluum. MA Daarul Uluum merupakan sekolah yang berkualitas dan bernuansa pesantren di Kota Bogor yang mempunyai Visi " Menjadi lembaga pendidikan islam terpadu yang unggul, sehat, berdisiplin, dan berwawasan global" (dokumen pesantren 2017-2018). Selain itu juga MA Daarul Uluum Merupakan sekolah menegah satu-satunya yang berada di Kota Bogor dimana semua siswanya harus memukim atau tinggal di asrama. MA Daarul Uluum Bantar Kemang ini menawarkan berbagai keunggulan dalam kegiatan Belajar Mengajar (KBM) dan Mendidik meliputi etika, aqidah, dan perilaku sesuai ajaran Islam. Mengajar meliputi pengetahuan dasar, wawasan keilmuan, dan akademis praktisi. MA Daarul Uluum pula mengutamakan keunggulan dalam Kegiatan ektrakurikuler, terdapat banyak sekali kegiatan ektrakurikuler disana yang menjadi keunggulan dalam berprestasi baik ditingkat regional dan nasional. Contohnya: Pramuka, jamiatul quro, kitab kuning, marawis, hadroh, teater, drum band, bahasa persia, latihan pidato 3 bahasa, MHQ dan lain sebagainnya. Prestasi dan inovasi tersebutlah yang menjadi salahsatu senjata lembaga ini dalam menerapkan strategi pemasaran untuk merekrut siswanya.

Namun, dibalik semua itu, MA Daarul Ulum juga dituntut untuk terus bisa berkembang dan eksis mengikuti perkembangan zaman sehingga dapat memenuhi tuntunan dan permintaan stakeholder yaitu menghasilkan lulusan yang berkualitas dan berkarakter, baik secara intelektualitas, moralitas maupun kemandirian hidup yang berkarakter. 
Terlebih dengan semakin ketatnya persaingan antar lembaga pendidikan yang memiliki sistem pendidikan yang sama dengan MA Daarul Uluum, maka dari itu jika tidak diimbangi dengan strategi pemasaran jasa pendidikan yang matang, pengembangan kualitas yang semakin baik, juga tentunya pelayanan yang sangat memuaskan, maka lambat laun sekolah MA Daarul Uluum akan tertinggal dengan lembaga-lembaga yang baru yang menawarkan berbagai keunggulan dan kelebihan.

Hal ini yang perlu di catat oleh pihak Ma Daarul Uluum, sehubungan dengan perkembangan lembaga ini, sebagaimana hasil wawancara dengan kepala Tata Usaha. Setidaknya dalam tiga tahun terakhir ini jumlah siswa dari tahun ke tahun selalu naik. Adapun jumlah siswa di MA Daarul Uluum dari tahun 2015/2016 jumlah siswa adalah 98 orang dengan rincian kelas $\mathrm{X}$ jumlah siswa laki-laki 21 dan perempuan berjumlah 21, kelas XI jumlah siswa laki-laki berjumlah 10 dan siswa perempuan berjumlah 17, kelas XII jumlah siswa lakilaki berjumlah 13 dan siswa perempuan berjumlah 16, Pada tahun 2016/2017 jumlah siswa 93 orang dengan rincian kelas $\mathrm{X}$ jumlah siswa laki-laki 12 dan perempuan berjumlah 19, kelas XI jumlah siswa laki-laki berjumlah 18 dan siswa perempuan berjumlah 17, kelas XII jumlah siswa lakilaki berjumlah 10 dan siswa perempuan berjumlah 17. Dan pada tahun 2017/2018 jumlah siswa 119 orang dengan rincian kelas 10 jumlah siswa laki-laki 20 dan perempuan 27 orang, kelas II jumlah siswa laki-laki 14 dan perempuan 26, dan kelas 12 jumlah siswa laki-laki 13 dan perempuan 19.

\section{MATERI DAN METODE}

Metode yang digunakan pada penelitian ini adalah metode penelitian studi kasus dengan pendekatan kualitatif. Penelitian studi kasus yaitu penelitian yang berusaha menggambarkan dan menginterprentasikan objek sesuai dengan apa adanya (Sukardi 2009). Penelitian kualitatif adalah penelitian yang menekankan pencarian makna, pengertian, konsep, karakteristik, gejala, simbol, maupun deskripsi tentang suatu penomena fenomena; pokus dan multi metode, bersifat alami dan holistik. Dari sisi lain tujuan penelitian kualitatif adalah menemukan jawaban terhadap suatu fenomena atau pertanyaan melalui aplikasi prosedur ilmiah secara sistematis dengan menggunakan pendekatana kualitatif (Yusuf, 2015).

\section{Teknik Pengumpulan Data}

Teknis pengumpulan data pada penelitian ini menggunakan penelitian ini menggunakan teknik observasi, wawancara, dan studi dokumentasi. Jenis observasi yang digunakan dalam penelitian ini adalah observasi berperan serta terlibat dengan kegiatan sehari-hari orang yang sedang atau yang digunakan sebagai sumber dan penelitian. Wawancara dengan menggunakan tidak terstruktur dan struktur. Dokumen yang digunakan berupa dokumen-dokume seperti, buku panduan, koran, brosur, catatan, transkip, buku, surat kabar, majalah, prasasti, notulen rapat, dan sebagainnya (Arikunto, 2013).

\section{Teknik Analisis Data}

Teknik analisi data dalam penelitian ini menggunakan teknik analisis data kualitatif. Komponen analisis dalam penelitian ini berupa reduksi data, penyajian data, dan verifikasi. 


\section{Pemeriksaan Keabsahan Data}

Pemeriksaan keabsahan data dilakukan dengan teknik triangulasi, serta menggunakan jenis triangulasi metode dan triangulasi sumber.

\section{HASIL DAN PEMBAHASAN}

\section{Strategi Pemasaran Jasa Pendidikan di MA Daarul Uluum Bantar Kemang}

Dalam hal strategi pemasaran jasa pendidikan MA Daarul Uluum Bantar Kemang selalu memperhatikan manajemen pemasaran, unsur-unsur strategi pemasaran dan memperkuat bauran pemasaran, yakni melakukan perencanaan, pengorganisasian, pelaksanaan, evaluasi, segmentasi, targeting, positioning dan tentunya memperhatikan persaingan pasar yang ada pada saat itu dan selalu mengikuti perkembangan zaman. Dari hasil wawancara dengan wakil kepala bidang kesiswaan menyatakan bahwa MA Daarul Uluum bantar kemang telah melakukan perumusan unsur strategi dulu sebelum melakukan strategi pemasaran, agar segala hambatan yang ada dalam pelaksanaan strategi pemasaran dapat teratasi. Sebagai solusi MA Daarul Uluum telah meluruskan langkah-langkah atau tahapan-tahapan penting dalam strategi pemasaran jasa pendidikan, antara lain yaitu sebagai berikut.

\section{Perencanaan Penyusunan Strategi Pemasaran MA Daarul Uluum}

Langkah awal yang dilakukan oleh sekolah Ma Daarul Uluum adalah perencanaan penyusunan strategi pemasaran, proses penyusunan strategi pemasaran ini dilakukan pada jauh-jauh hari sebelum penerimaan mahasiswa baru, biasanya dilakukan delapan bulan sebelum sekolah
MA Daarul Uluum melakukan open rekruetmen siswa baru.

\section{Strategi Pengelompokan Pasar}

Segmentasi sekolah MA Daarul uluum sangat jelas, karena MA Daarul Uluumini berbasis pesantren. Segmentasinya adalah bagi siswa yang mau sekolah sambil pesantren, kemudian siswa yang mau meningkatkan pemahaman dan pengetahuan tentang keislaman yang lebih kuat dan mendalam. Karena Ma Daarul Uluum ingin berusaha mencetak alumnialumni yang memiliki ilmu amaliyah dan beramal ilmiyah ( hasil wawancara dengan kepala sekolah MA Daarul Uluum, Ustad Hasbulloh).

\section{Strategi Target Pasar Sasaran}

Menurut panitia penerimaan mahasiswa baru (PAPENSIBA) Bapak Rizal Azizi S. Pd. Telah mengatakan bahwa menentukan target pasar itu sangatlah penting sebelum melaksanakan strategi pemasaran, karena bertujuan untuk merekrut calon siswa baru yang akan mendaftar ke Ma Daarul Uluum Bantar Kemang. Target pasar yang diambil oleh MA Daarul Uluum adalah siswa siswi MTS dan SMP yang berada di daerah Jawa Barat seperti, Bogor, Sukabumi, Cianjur, Bekasi, Karawang, bahkan sampai ke luar Jawa Barat, dan lain sebagainya.

\section{Stategi Penentuan Pasar}

Banyaknya sekolah menengah atas yang ada di wilayah Kota Bogor, menunjukan bahwa persaingan antar sekolah masih tetap ada dan semakin ketat. Setiap lembaga pendidikan yang berada di Kota Bogor ini mempunyai keunggulan dan kekuatan tersendiri dalam mempertahankan eksistensi lembaganya. Begitu halnya dengan MA Daarul Uluum Bantar Kemang mempunyai Brand tersendiri yang 
membedakan dengan sekolah lainnya yang berada di kota bogo, perbedaan tersebut yaitu dengan adanya brand pondok pesantren moderen yang mempunyai ciri khas seluruh siswa dan siswinya semuanya wajib bermukim atau tinggal diasrama, kemudian program ngaji kitab kuning setiap hari, bahasa sehari-hari bahasa inggris dan bahasa arab, mengahsilkan alumni- alumni yang berkualitas, meskipun MA Daarul Uluum ini lebih mengusung unsur keagaamaan yang kuat, namun MA Daarul Uluum pun sangat memperhatikan dan tidak melupakan kegiatan intrakulikuler dan ekstrakulikuler, bahkan MA Daarul Uluum ini mempunyai 23 jenis kegiatan intrakulikuler dan mempunyai 23 jenis kegiatan ektrakulikuler. Jadi ini yang membedakan antara MA Daarul Uluum dengan Madrasah-madrasah lainnya, sehingga sekolah ini masih tetap eksis di kalangan masyarakat. Tentunya pihak Ma Daarul Uluum ingin dan berharap agar semua siswa-siswinya berhasil dan sukses di dunia dan di akhirat.

\section{Pengorganisasian Panitia PAPENSIBA}

Pengorganisasian merupakan proses penyusunan dan pengelompokkan manusia yang terbentuk dalam sebuah struktur. Kemudian dalam struktur tersebut dijelaskan tugas dan fungsi yang harus dilaksanakan berdasarkan rencana yang telah dirumuskan dan ditetapkan. Hal ini sangtlah perlu karena agar tidak terjadi tumpang tindih dalam melaksanakan tugas dan fungsinya.

Langkah selanjutnya yang dilakukan oleh pihak MA Daarul Uluum Bantar Kemang yaitu pengorganisasian sumber daya manusia yang ada yaitu dengan membentuk kepanitian penerimaan siswa baru (PAPENSIBA). Agar proses pemasaran sekolah MA Daarul Uluum bisa terarah dan terpola secara baik dan benar. Adapun struktur kepanitian mahasiswa baru (PAPENSIBA) MA Daarul Uluum seperti pada Tabel 1.

Tabel 1 Struktur PEPENSIBA

\begin{tabular}{|c|c|c|}
\hline No & Nama & Jabatan \\
\hline 1 & $\begin{array}{l}\text { Mudir al- } \\
\text { MA'had }\end{array}$ & Penanggung jawab \\
\hline 2 & $\begin{array}{l}\text { Rizal Azizi, } \\
\text { S. Pd }\end{array}$ & Koordinator Umum \\
\hline 3 & Alphi Parati & $\begin{array}{l}\text { Urusan informasi, } \\
\text { keuangan, } \\
\text { administrasi }\end{array}$ \\
\hline 4 & $\begin{array}{l}\text { Hasbulloh, } \\
\text { SE, MA, Ek. }\end{array}$ & $\begin{array}{l}\text { Urusan penggalangan } \\
\text { santri }\end{array}$ \\
\hline 5 & $\begin{array}{l}\text { Lulu Zahroh } \\
\text {, S. Psi. }\end{array}$ & $\begin{array}{l}\text { Urusan testing dan } \\
\text { penjaringan }\end{array}$ \\
\hline 6 & $\begin{array}{l}\text { Yaser Al- } \\
\text { Arusyi, ST. }\end{array}$ & $\begin{array}{l}\text { Urusan } \\
\text { kerumahtanggaan dan } \\
\text { asrama }\end{array}$ \\
\hline 7 & $\begin{array}{l}\text { Pembantu } \\
\text { Umum }\end{array}$ & $\begin{array}{l}\text { Seluruh dewan guru, } \\
\text { karyawan, pengurus } \\
\text { hisada, dan alumni. }\end{array}$ \\
\hline
\end{tabular}

\section{Pelaksanaan Strategi Pemasaran MA Daarul Uluum}

Setelah melaksanakan perumusan dalam melaksanakan strategi pemasaran, maka langkah selanjutnya MA Daarul Uluum baru bisa menerapkan strategi pemasaran, ada dua cara strategi pemasaran jasa pendidikan yang dilakukan oleh pihak MA Daarul Uluum Bantar Kemang, yaitu pemasaran secara langsung dan pemasaran secara tidak langsung.

\section{Evaluasi dalam Panitia Penerimaan Siswa Baru (PAPENSIBA)}

Evaluasi merupakan langkah terkahir yang dilakukan oleh pihak MA Daarul Uluum dalam strategi pemasaran. Evaluasi ini dilaksanakan setiap tahun satu kali, dan 
melibatkan seluruh stake holder yang berada di MA Daarul Uluum. Agar semua rencana dan program kerja yang telah disusun dengan baik, maka selanjutnya evaluasi dalam menjalankan tugas Panitia penerimaan siswa baru (PAPENSIBA) menjadi hal yang sangat penting untuk dilaksanakan oleh MA Daarul Uluum Bantar Kemang. Evaluasi ini dilakukan agar program kerja yang telah dibuat tidak keluar dari hal yang telah direncanakan.

Menurut bapak Fikri Aziz, S. Pd. selaku waka kesiswaan mengatakan bahwa dalam persaingan pada saat ini pun sangatlah ketat khususnya di kota Bogor ini, maka dalam mengatasi dan menghadapi persaingan yang sangat ketat ini evaluasi merupakan hal yang sangat penting yang harus dilakukan oleh pihak MA Daarul Uluum Bantar Kemang, yaitu dengan cara tetap menjaga kualitas dan meningkatkan pelayanan jasa yang dimiliki oleh MA Daarul Uluum Bantar Kemang agar bisa bertahan dan lebih maju dibanding sekolah lainnya.

\section{Implementasi Strategi Pemasaran Jasa Pendidikan di MA Daarul Uluum Bantar Kemang dengan Menggunakan Bauran Pemasaran}

\section{Produk}

Keunggulan sekolah MA Daarul Uluum Bantar Kemang dalam hal produk yaitu ada dua keunggulan yakni dalam bidang intrakulikuler dan bidang ektrakulikuler.

1. Intrakulikuler, mempunyai guru yang profesional dalam dalam menyampaikan ilmunya dan sesuai dengan bidangnya masing-masing, guru di MA Daarul Uluum 95\% sudah sertifikasi guru. Adanya program pendukung seperti: wajib tinggal dipondok (asrama) dan hidup dalam ritme kegiatan yang sudah diatur selam 24 jam, wajib mnggunakan bahasa arab dan inggris dalam berkomunikasi sehari-hari, baik didalam kelas maupun diluar kelas, berdisiplin dalam segala hal, sesuai dengan ketentuan masing masing.

2. Ektrakulikuler, seperti kajian kitab salafi ba'da subuh sampai jam 06.00 WIB, pembinaan tahfidz Al-Quran dan seni tilawahnya, training metode pengajaran Al-Qur'an, latihan berceramah dalam tiga bahasa: Arab, Inggris, dan Indonesian, pelatihan menulis, Forum diskusi Ilmiah dan lain sebainnya.

Dari program-program diatas, sekolah telah berupaya memberikan program yang terbaik bagi siswa yang sesuai dengan kebutuhannya. Dengan adanya programprogram tersebut, maka sangat memberikan nilai tambah tersendiri bagi MA Daarul Uluum Bantar Kemang dalam meningkatkan kualitas yang dimiliki dibandingkan dengan sekolah swasta lainnya. Program-program tersebuat juga menjadi strategi pemasaran jasa pendidikan untuk meningkatkan kuantitas siswa setiap tahunnya dan agar lebih dikenal oleh masyarakat lebih luas.

\section{Harga (Price)}

Sekolah MA Daarul Uluum dalam menentukan kebijakan anggaran pembayaran siswa sudah ditentukan setiap tahun sekali dirapat tahunan, dan besar anggaran siswanya 650.000/bulan, besar anggaran ini cukup sesuai dengan pelayanan dan fasilitas yang diberikan oleh pihak MA Daarul Uluum. Rincian biaya MA Daarul Uluum Bantar Kemang terdapat pada Tabel 2. 
Tabel 2 Rincian biaya pendaftaran

\begin{tabular}{lll}
\hline No & \multicolumn{1}{c}{ Variabel } & \multicolumn{1}{c}{ Jumlah } \\
\hline 1 & Infaq Pendaftaran & 250.000 \\
2 & Infaq pengembangan & 2.000 .000 \\
& pesantren & \\
3 & Sarriyah/ Bulanan & 650.000 \\
4 & Kaos Olahraga & 200.000 \\
5 & Seragam bela diri & 250.000 \\
6 & Seragam khusus & 200.000 \\
& meninggalkan pesantren & \\
7 & Lemari pakaian & 625.000 \\
8 & Kasur dan bantal & 425.000 \\
Jumlah & 4.600 .000 \\
\hline
\end{tabular}

\section{Promosi (Promotion)}

Promosi merupakan bagian terpenting dalam memasarkan jasa pendidikan. Promosi yang dilakukan oleh pihak MA Daarul Uluum itu ada 2 cara yaitu promosi secara langsung dan promosi secara tidak langsung.

1. Promosi secara langsung, seperti: a) melakukan kunjungan-kunjungan ke MTS dan SMP maupun negeri atau swasta yang bertujuan untuk mempromosikan MA Daarul Uluum Bantar Kemang kepada siswa-siswi agar mereka tertarik dan melanjutkan ke MA Daarul Uluum, b) promosi melalui media online seperti wibsite (http:// www.Daarululuum.co.id), facebook, ig, dan lain sebagainnya, yang berisi faktafakta, seperti lokasi, prestasi siswa, kegiatan siswa dan lain sebagainnya. c) mempromosikan sekolah dengan cara ikut serta diberbagai ajang perlombaan yang dilakukan oleh pihak-pihak tertentu yang lingkupnya tingkat provinsi bahkan nasional. d) mempromosikan sekolah dengan cara mengadakan perlombaan-perlombaan tingkat SMP dan MTS tingkat provinsi. e) mempromosikan sekolah melalui media cetak, yaitu melalui brosur, pamplet, bener, dan spanduk.

2. Promosi secara tidak langsung: a) mempererat tali silaturahmi dengan masyarakat melalui masjid yaitu dengan cara ikut terlibat dalam kegiatankegiatan yang ada di masyarakat khususnya daerah bantar kemang, seperti santri diikut sertakan dalam kepanitiaan peringatan-peringatan hari besar, menjadi khotib dalam sholat jumat, ikut mensholati jenazah ketika ada yang meninggal dan menghadiri undangan untuk menjadi pengisi acara di nikahan (marawis, hadroh, qori dan sebagainnya). b) mengadakan bakti sosial kepada masyarakat, berupa: pembagian daging qurban, santunan anak yatim dan pakir miskin, dan lain sebagainnya.

\section{Tempat (Place)}

Lokasi MA Daarul Uluum sangatlah strategis karena berada di tengah-tengah Kota Bogor, lokasinya tepat berada di pinggir jalan raya, dan mudah dijangkau oleh seluruh stake holder baik yang menggunakan kendaraan pribadi atau pun menggunakan kendaraan umum.

\section{Sumber Daya Manusia (People)}

Sumber daya manusia yang dimiliki oleh MA Daarul Uluum Bantar Kemang sangatlah kuat dan berkualitas karena 95\% guru yang berada di MA Daarul Uluum sudah sertifikasi, mengajar di bidang ahlinya masing-masing dan srata pendidikannya minimal S1 dan bahkan sudah banyak yang sudah S2. Hal ini pun menjadi salah-satu keunggulan yang dimiliki oleh pihak Ma Daaru Uluum dalam strategi pemasaran jasa pendidikan. 


\section{Sarana dan Prasaran (Pysical Evidance)}

Keaadaan bukti fisik yang dimiliki oleh MA Daarul Uluum Bantar Kemang cukup menunjung bagi berlangsungnya proses pembelajaran. Adapun keaadaan fakta bukti fisik dimiliki oleh MA Daarul Uluum Bantar kemang adalah: kantor yayasan, ruang kelas, ruang kamar, ruang guru, ruang tata usaha, laboratorium, perpustakaan, ruang seni, ruang BP, ruang UKS, ruang aula, mesjid, kantin, koperasi, kantor osis, rumah kamad, asrama guru, asrama siswa.

\section{Proses (Process)}

Proses ini merupakan aktivitas kegiatan secara menyeluruh dari awal sampai akhir. Mulai dari proses strategi pemasaran (pendaptaran, penyambutan), proses marxeting mix (dari sisi produk, tenmpat harga, promosi, orang, sarana, melakukan penyesuaian, perencanaan yang matang), kemudian proses pendidikan (menjalankan reword and panismen sesuai dengan ketentuan yang sudah dimiliki sekolah, kemudian di akhir sekolah memberikan sebuah penghargaan kepada siswa-siswi yang berprestasi.

\section{Faktor Pendukung Strategi Pemasaran Jasa Pendidikan di MA Daarul Uluum Bantar Kemang}

Dalam melaksanakan pemasaran jasa pendidikan di MA Daarul Uluum Bantar Kemang tentunya tedapat beberapa faktor pendukung, diantaranya adalah: 1) letak sekolah yang sangat strategis, berada di tengah-tengah Kota Bogor mudah dijangkau oleh transfortasi pribadi atau transfortasi umum, berada disisi jalan raya, dan dekat dengan instansi-instansi pemerintahan. 2) berada langsung di bawah naungan Yayasan Daarul Uluum. 3) kepercayaan masyarakat yang begitu tinggi. 4) Anggran Pembiaian yang cukup murah sehingga terjangkau oleh kalangan manapun. 5) memiliki kegiatan ektrakulikuler yang banyak dan beragam. 6) tenaga pendidik yang berkualitas

\section{Faktor Penghambat Strategi Pemasaran Jasa Pendidikan di MA Daarul Uluum Bantar Kemang}

1. Persaingan antar lembaga yang semakin kuat dan semakin ketat, solusinya MA Daarul Uluum selalu mengikuti perkembangan zaman, menciptakan inovasi-inovasi baru yang tidak dimiliki oleh sekolah lain, mempertahankan dan mengembangkan prestasi yang sudah ada baik dibidang akademik maupun bidang non akademik, menjalin hubungan yang baik dengan masyarakat dan selalu menjaga kepercayaan masyarakat.

2. Belum ada tenaga ahli yang khusus menangani dibidang strategi pemasaran.

3. Parkiran kendaraan yang terbatas, sehingga ada acara-acara yang sifatnya mengundang banyak orang dari luar, itu sangat susah untuk dikondusifkan.

4. Kurangnya lahan untuk olahraga, lahan yang dimiliki oleh MA Daarul Uluum Bantar Kemang sekarang ini baru memiliki satu buah lapangan yang berada didepan ruangan kelas.

5. Kurang luasnya tanah yang dimiliki sekolah sehingga sulit untuk menambah ruangan baru, karena letaknya berada di Kota sehingga tidak ada lagi tanah yang kosong untuk dapat dibeli.

6. Keluar masuknya siswa-siswi MA Daarul Uluum, sehingga bagi yang memang cocok tinggal dilingkungan pondok pesantren pasti bertahan sedangkan yang tidak cocok di lingkungan pesantren pasti akan keluar. 
7. Sering hilangnya banner dan baliho yang sudah disebar di titik-titik tertentu.

\section{KESIMPULAN DAN IMPLIKASI}

\section{Kesimpulan}

1. Strategi pemasaran jasa pendidikan di MA Daarul Uluum Bantar Kemang cukuk baik, karena pihak sekolah memiliki tahapan-tahapan yang ideal yaitu dengan menggunakan prinsip-prinsip manajeman dalam pelaksanaan strategi pemasaran.

2. Implementasi strategi pemasaran dengan menggunakan bauran pemasaran di MA Daarul Uluum Bantar Kemang sangat berhasil dan efektif, karena dengan produk, promosi, tempat, harga, orang, sarana dan prasarana, dan proses yang dimiliki pihak MA Daarul Uluum bisa meningkatkan jumlah animo pendaftar peserta didik disetiap tahunnya. Sehingga MA Daarul Uluum masih tetap eksis di dunia pendidikan dan menjadi alternatif orang tua untuk menyekolahkan anaknya.

3. Faktor pendukung dalam strategi pemasaran jasa pendidikan di MA Daarul Uluum diantaranya, tenaga pendidik yang berkualitas, letak sekolah yang geografis, memilki banyak kegiatan ektrakulikuler, langsung berada dibawah naungan Yayasan Daarul Uluum, dan anggaran pembiaiaan sekolah yang terjangkau oleh kalangan manapun.

4. Faktor penghambat dalam pelaksanaan strategi pemasaran jasa pendidikan di
MA Daarul Uluum Bantar Kemang yaitu : persaingan antar lembaga yang semakin ketat, belum ada tenaga ahli dibidang pemasaran, parkiran kendaraan yang sangat terbatas, kurangnya lahan untuk olahraga, kurang luasnya tanah yang dimiliki oleh sekolah, dan keluar masuknuya siswa-siswi MA Daarul Uluum Bantar Kemang.

\section{Implikasi}

Bagi Pihak Lembaga, agar lebih mendalami tentang strategi pemasaran jasa pendidikan. Untuk pihak Umum, diharapkan dapat melakukan penelitian yang lebih mendalam dengan obyek yang berbeda, lebih menggali informasi dan data-data pada orangorang/lembaga yang terkait dengan strategi pemasaran jasa pendidikan dalam meningkatkan kuantitas siswa.

\section{DAFTAR PUSTAKA}

Alma, B. (2005). Pemasaran strategik jasa pendidikan. Alfabeta: Bandung.

Arikunto, S. (2013). Prosedur penelitian (Suatu Pendekatan Praktik). Rineka Cipta: Jakarta.

Sukardi. (2009). Metodologi penelitian pendidikan kompetensi dan praktiknya. Bumi Aksara: Jakarta.

Wijaya, D. (2012). Pemasaran Pendidikan. Salemba Empat : Jakarta.

Yusuf, A. M. (2015). Metode penelitian kuantitatif, Kualitatif, dan penelitian gabungan. Pranada Media Group : Jakarta. 